\title{
Lectin, hemolysin and protease inhibitors in seed fractions with ovicidal activity against Haemonchus contortus
}

\author{
Lectina, hemolisina e inibidores de protease em frações de sementes com \\ atividade ovicida contra Haemonchus contortus
}

Hévila Oliveira Salles ${ }^{1 *}$; Ana Carolina Linhares Braga ${ }^{2}$; Maria Thayana dos Santos Canuto do Nascimento ${ }^{3}$; Ana Márjory Paiva Sousa ${ }^{3}$; Adriano Rodrigues Lima ${ }^{1}$; Luiz da Silva Vieira ${ }^{1}$; Antônio Cézar Rocha Cavalcante ${ }^{1}$; Antonio Silvio do Egito $^{1}$; Lúcia Betânia da Silva Andrade ${ }^{3}$

\author{
${ }^{1}$ Embrapa Caprinos e Ovinos, Sobral, CE, Brasil \\ ${ }^{2}$ Instituto Superior de Teologia Aplicada - INTA, Sobral, CE, Brasil \\ ${ }^{3}$ Universidade Estadual Vale do Acaraú - UVA, Campus da Betânia, Sobral, CE, Brasil
}

Received October 21, 2013

Accepted April 2, 2014

\begin{abstract}
Bioactive molecules of plant species are promising alternatives for the chemical control of gastrointestinal nematodes in ruminants. Extracts of native and exotic seed species from Brazil's semi-arid region were tested in vitro in an egg hatch assay and the bioactivity of their proteins was investigated. Each seed species was subjected to three extractions with three types of solvents. All the seeds showed ovicidal activity, which varied according to the solvents. Higher ovicidal activity was found in the molecule fractions of low molecular weight $(<12 \mathrm{kDa})$ for Albizia lebbeck, Ipomoea asarifolia, Jatropha curcas, Libidibia ferrea, Moringa oleifera and Ricinus communis ( $\mathrm{P}<0.05$, Bonferroni test). The two fractions of Crotalaria spectabilis showed the same ovicidal activity ( $>0.05$, Bonferroni test). Hemagglutinating activity was detected in the fractions of $C$. spectabilis and M. oleifera fractions, hemolysin activity in the A. lebbeck and M. oleifera fractions, serine protease inhibitory activity in the A. lebbeck, I. asarifolia, J. curcas, M. oleifera and R. communis fractions, cysteine protease inhibitor activity in the $M$. oleifera fraction, and no protein activity in the $L$. ferrea fraction. The results of this work reveal new plant species with a potential for use in controlling nematode parasites in goats, thus opening a new field of research involving plant protein molecules with ovicidal properties.
\end{abstract}

Keywords: Goats, nematodes, egg hatch assay, lectin, protease inhibitors, hemolysin.

\section{Resumo}

Moléculas bioativas de espécies vegetais são alternativas promissoras ao controle químico dos nematoides gastrintestinais em ruminantes. Extratos de sementes de espécies nativas e exóticas do Semiárido Brasileiro foram testados in vitro em ensaio de eclosão de ovos e investigada a natureza proteica da bioatividade. Três extraçóes com três solventes foram feitas para cada semente estudada. Todas as sementes apresentaram atividade ovicida, variando com o solvente utilizado. Maior taxa de inibição da eclosão concentrou-se nas fraçôes de moléculas de baixa massa molecular $(<12 \mathrm{kDa})$ para Albizia lebbeck, Ipomoea asarifolia, Jatropha curcas, Libidibia ferrea, Moringa oleifera e Ricinus communis $(\mathrm{P}<0,05$, teste de Bonferroni). Crotalaria spectabilis mostrou atividade nas duas fraçóes, sem diferença entre elas ( $\mathrm{P}>0,05$, teste de Bonferroni). Observou-se atividade hemaglutinante nas fraçóes de C. spectabilis e $M$. oleifera, de hemolisina em $A$. lebbeck e $M$. oleifera, de atividade inibidora de protease da serina em $A$. lebbeck, I. asarifolia, J. curcas, $M$. oleifera e $R$. communis, de atividade inibidora de protease da cisteína em $M$. oleifera e nenhuma atividade proteica na fração de L. ferrea. Os resultados revelaram novas espécies botânicas com potencial de controle de nematoides em caprinos e um novo campo de pesquisa, o estudo de moléculas de origem proteica com atividade ovicida.

Palavras-chave: Caprino, nematoide, ensaio de eclosão de ovos, lectina, inibidores de proteases, hemolisina.

\footnotetext{
*Corresponding author: Hévila Oliveira Salles

Embrapa Caprinos e Ovinos, CP 145, CEP 62010-970, Sobral, CE, Brasil

e-mail: hevila.salles@embrapa.br
} 


\section{Introduction}

Gastrointestinal nematodes (GIN) in domesticated livestock are of major global economic importance. Two species predominate in regions with tropical and subtropical climates: Haemonchus contortus and Trichostrongylus colubriformis, the former being the main nematode species that parasites small ruminants (AMARANTE et al., 2004).

The control of gastrointestinal parasitism has been based on the intensive and uninterrupted administration of synthetic anthelmintics, which has led to the development of resistant populations of nematodes. Actually, however, to meet the growing demand for food production involving a minimal degradation of natural resources, especially for food produced with the correct use or no use of chemicals, the discovery of plant molecules with ovicidal properties offers an excellent alternative for nematode control (GITHIORI et al., 2006).

Several plants possess peculiar features that set them apart because they are more resistant to adversities caused by physical and/or organic agents. This resistance may be due to the constitutive or post-inductive expression of bioactive molecules.

Most of the studies that have searched for anthelmintic molecules in plant extracts focused on the presence of secondary metabolites. For example, in the most active extracts for egg hatch inhibition, Maciel et al. (2006) demonstrated the presence of condensed tannins, triterpenes and alkaloids. However, plants defend themselves against pathogens and insect pests in various ways. Both monocot and dicot seeds contain various proteins whose function is to store nutrients for germination and growth. Other proteins in seeds are believed to have functions such as protection against pathogens and insects, among which lectins and protease inhibitors stand out (CARLINI; GROSSI-DE-SÁ, 2002).

Lectins or hemagglutinins are proteins/glycoproteins, which have at least one non-catalytic domain that exhibits reversible binding to specific monosaccharides or oligosaccharides. They may bind to the carbohydrate moieties on the surface of erythrocytes and agglutinate the erythrocytes without altering the properties of the carbohydrates (LAM; NG, 2011a).

Many studies have shown the presence of carbohydrates on GIN surfaces, using labeled lectins (BONE; BOTTJER, 1985; PALMER; McCOMBE, 1996; JURASEK et al., 2010; HILLRICHS et al., 2012). In these studies, Concanavalin A (ConA), Lens culinaris agglutinin (LCA), Maclura pomifera agglutinin (MPA), peanut agglutinin (PNA) and Pisum sativum agglutinin (PSA) were bound to the egg surfaces, suggesting the presence of glucose, mannose and galactose carbohydrates.

The toxic effect of lectins on egg hatching has not yet been evaluated, but Ríos-de Álvarez et al. (2012) recently detected the inhibitory effect of plant lectins on the in vitro feeding behavior of the first larval stage of GIN in sheep. Therefore, the field is open to find toxic lectins for GIN eggs.

The hatching and subsequent release of first-stage larvae of $H$. contortus are believed to result from a combination of mechanical and enzymatic events (ROGERS; BROOKS, 1977). The eggshell of $H$. contortus consists of three basic layers containing proteins , an outer vitelline layer, a middle chitinous layer and an inner lipid layer, that are digested during hatching (MANSFIELD et al., 1992). In addition, like embryonic development, proteolysis is an essential metabolic process required for protein processing. The cysteine proteases that are present in the embryonic and larval stages of parasites suggest that these proteases may function in ways related not only to the development of parasitism and nutrition digestion but also to the embryonic and larval development (HASHMI et al., 2002; YANG et al., 2011). Therefore, protease inhibition may be another strategy to control parasites.

Protease inhibitors in plants often accumulate in storage tissues, such as seeds and tubers, and a common characteristic of all of these inhibitors is that they are small and display an overall stability that helps minimize the loss of entropy when the inhibitor binds to the enzyme. This structural stability is due to features such as disulfide bonds, hydrogen bonds, compact size and even the cyclization of the $\mathrm{N}$ - and C-termini (BATEMAN; JAMES, 2011).

To find an effective molecule against nematode eggs, first is required in vitro screening tests, being the extraction conditions optimized by systematically varying parameters such as the composition of the extraction medium. Therefore, it is important to find an extraction solvent in which the protein of interest remains stable and in which it is most efficiently released from the cells or tissue. The proper design of an extraction method thus requires preliminary experiments in which aliquots are taken with various extraction solvents and analyzed for activity and protein content.

The purpose of this study was to evaluate the ovicidal activity of some seeds from native and exotic plant species widely available in Brazil's semi-arid region, using three distinct solvents normally used for protein extraction, and investigate the bioactivity of their proteins in the most active fractions of the extracts.

\section{Materials and Methods}

\section{Plant material and extraction}

The seeds in question, which came from Albizia lebbeck, Crotalaria spectabilis, Ipomoea asarifolia, Jatropha curcas, Libidibia ferrea, Moringa oleifera and Ricinus communis, were collected from plants growing in the wild or cultivated at EMBRAPA's Goat and Sheep farm, as authorized by IBAMA - Brazilian Institute of Environment and Renewable Natural Resources (Permit \# 02/2008, process 02001.008512/2011-09).

The seeds were ground in a coffee grinder and extracted under constant shaking for one hour at $25^{\circ} \mathrm{C}$, using ten volumes of solvents $(\mathrm{w} / \mathrm{v})$. Three solvents were used for protein extraction: distilled water, $150 \mathrm{mM} \mathrm{NaCl}$, and $25 \mathrm{mM}$ Tris- $\mathrm{HCl}, \mathrm{pH} 7.5$, with three extractions done with each of them. The suspensions were centrifuged for $30 \mathrm{~min}$ at $4{ }^{\circ} \mathrm{C}$ and at $10,000 \times g$. The supernatant (crude extract) recovered was used for the egg hatch assay.

\section{Fractionation of crude extract}

Crude extracts from each plant which showed the highest ovicidal activity were selected among the three extraction solvents, been dialyzed for $24 \mathrm{~h}$ at $8{ }^{\circ} \mathrm{C}$ in a proportion of 1:10 (crude 
extract: extraction solvent). The fraction of crude extract retained (CER) in the dialysis membrane (cutoff $12 \mathrm{kDa}$ ) and the fraction not retained (CENR) were tested in the egg hatch assay. The most active one was examined for hemagglutination, hemolysin and proteases inhibition activity.

\section{Protein concentration}

Protein concentration was determined as described by Bradford (1976), using bovine serum albumin (BSA) as standard.

\section{Egg hatch assay}

A goat naturally infected with GIN and with an $H$. contortus infection rate of over $90 \%$ was used as a source of fresh eggs. A suspension $(0.1 \mathrm{~mL})$ of fresh GIN eggs $(n=100)$ was recovered from feces, as described by Hubert and Kerboeuf (1984), and placed in 24-well plates. Samples of $0.4 \mathrm{~mL}$ containing $0.1 \mathrm{mg}$ of protein were added to these wells. Albendazole $(0.5 \%$ in distilled water, w/v) was used as positive control. Controls of the solvents were also used. The plates were incubated for $24 \mathrm{~h}$ in a chamber at $27^{\circ} \mathrm{C}$, after which $5.0 \%$ formalin was added to stop egg hatching. A count was made of all the eggs and first-stage larvae $\left(\mathrm{L}_{1}\right)$ in each plate. The percentage of hatched eggs was determined using the following ratio: number of $\mathrm{L}_{1} /\left(\right.$ number of eggs + number of $\mathrm{L}_{1}$ ), and the percentage of egg hatch inhibition was determined using the following equation: 100 - (\% of hatched eggs in the samples * 100 / \% of hatched eggs in the control group). Three replicates were made of each tested sample.

\section{Hemagglutination assay}

Hemagglutination activity was measured by a serial dilution procedure using a $2 \%$ suspension of rabbit erythrocytes, as previously described by Carbonaro et al. (2000), with a few modifications. The assay was performed in 96-well U-bottom polystyrene microtiter plates, at a final volume of $0.1 \mathrm{~mL}$ containing $0.05 \mathrm{~mL}$ of $2 \%$ suspension of rabbit erythrocytes and $0.05 \mathrm{~mL}$ of 2 -fold serial sample dilution. Agglutination was visualized after $12 \mathrm{~h}$ at $25^{\circ} \mathrm{C}$. One hemagglutination unit (1 HU) was taken as the highest dilution causing complete agglutination of rabbit erythrocytes. Whenever hemolysin was detected in the hemagglutination assay, the sample was subjected to a hemolytic activity assay.

\section{Hemolytic activity assay}

Initially, the assay was performed according to the method described by Lam and $\mathrm{Ng}$ (2011b), which involved washing rabbit erythrocytes with phosphate-buffered saline (PBS, pH 7.2) and adjusting to a final concentration of $2 \%(\mathrm{v} / \mathrm{v})$ in PBS. Then, $0.2 \mathrm{~mL}$ of rabbit erythrocytes suspension was mixed in $0.2 \mathrm{~mL}$ of sample solution and incubated at $37{ }^{\circ} \mathrm{C}$ for $30 \mathrm{~min}$. After centrifugation at $14,000 \times g$ for $30 \mathrm{~s}$, the amount of hemoglobin released from disrupted erythrocytes was determined by measuring the supernatant's absorbance at $540 \mathrm{~nm}$. Control samples were run in parallel to measure spontaneous and complete lysis of erythrocytes. The erythrocytes were treated with $0.1 \%$ Triton-X 100 to obtain $100 \%$ lysis.

However, the samples showed higher readings than the positive control, invalidating this assay and suggesting the presence of molecules which absorb at $540 \mathrm{~nm}$. Thus, to determine the hemolytic activity, the results obtained in the hemagglutination assay were used, where one hemolytic unit (1 HU) was taken as the highest dilution causing complete hemolysis of rabbit erythrocytes.

\section{Protease inhibitor assay}

Trypsin and papain inhibitory activity was determined as described by Kakade et al. (1974) and Abe et al. (1992), respectively. Inhibitory activity was expressed as inhibitor units per mg of protein. One inhibitory unit (1 IU) was defined as the amount of inhibitor that decreased the absorbance by 0.01 in enzyme activity as compared with the protease incubated alone, i.e., without the analyzed sample. Analyzed samples were also incubated without proteases.

\section{Statistical analysis}

The experiments were carried out using a completely randomized design with three replications. Bonferroni test was used for multiple comparisons of the treatment groups. The level of significance was 0.05 .

\section{Results}

\section{Protein content}

Seeds contain reserve proteins such as albumins, globulins, prolamins and glutelins with different solubility in distinct solvents. The solvents used in this study enabled us to extract albumins with water and globulins and some albumins with saline solution. Using Tris-HCl buffer with $\mathrm{pH} 7.5$ allows albumins and globulins whose isoelectric point differs from 7.5 to be extracted together.

Figure 1 depicts the results of protein content in crude extracts. Note that the protein extraction solvents led to variations in the protein content in the same plant. The seed protein content also differed between plants, with $I$. asarifolia showing the highest protein content and A. lebbeck, J. curcas and L. ferrea the lowest, regardless of the extraction solvent used (Figure 1). These results can be attributed to the difference in the composition of the seed reserve proteins in each plant.

\section{Egg hatch assay}

In the egg hatch assay, the same amount of protein from the crude extracts was used per well (100 $\mu \mathrm{g}$ of protein). Assuming that the activity is of protein origin, comparisons can be made of the results obtained with different solvents in the same plant, between the different plants analyzed, and the positive control. 
Figure 2 illustrates the results of egg hatch inhibition of different crude extracts from the seven plants analyzed. Note that the best egg hatch inhibition rate of over $90 \%$ was detected in the crude water extracts of $A$. lebbeck and $M$. oleifera, and in the crude saline extracts from A. lebbeck, I. asarifolia and L. ferrea. These extracts were also more effective $(\mathrm{P}<0.05$, Bonferroni test $)$ than Albendazole $0.5 \%$ (positive control), which showed $84.13 \%$ of egg hatch inhibition. The C. spectabilis, J. curcas and $R$. communis extracts were less effective, but among them, the saline ones were the best. Egg hatch inhibition of over $90 \%$ was found only in

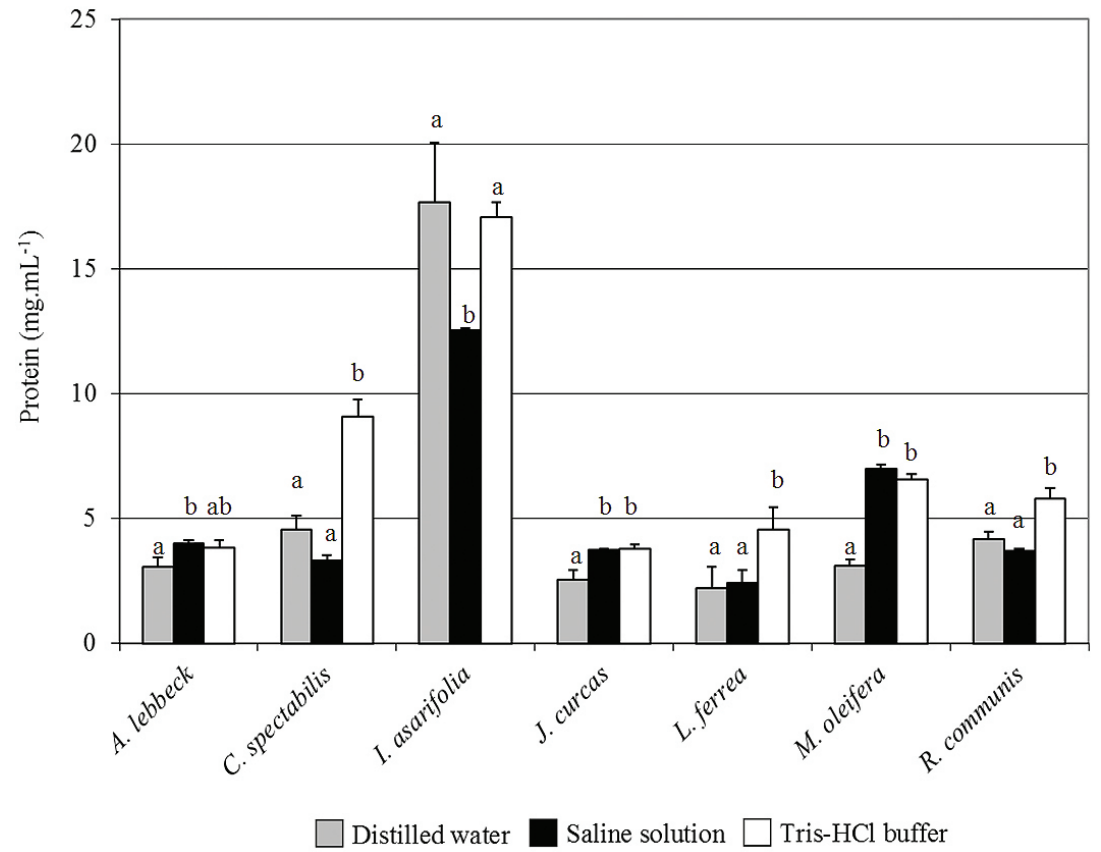

Figure 1. Protein concentration $(\mathrm{mg} / \mathrm{mL})$ in different extraction solvents and seeds. Protein content was determined according to Bradford (1976), using BSA as standard. Extraction solvents: distilled water; saline solution (150 mM NaCl); Tris- $\mathrm{HCl}$ buffer (25 mM Tris- $\mathrm{HCl}$, $\mathrm{pH}$ 7.5). Values are expressed as means \pm standard deviation. Different letters indicate statistically significantly differences $(\mathrm{P}<0.05)$ between extraction solvents in each plant (Bonferroni test).

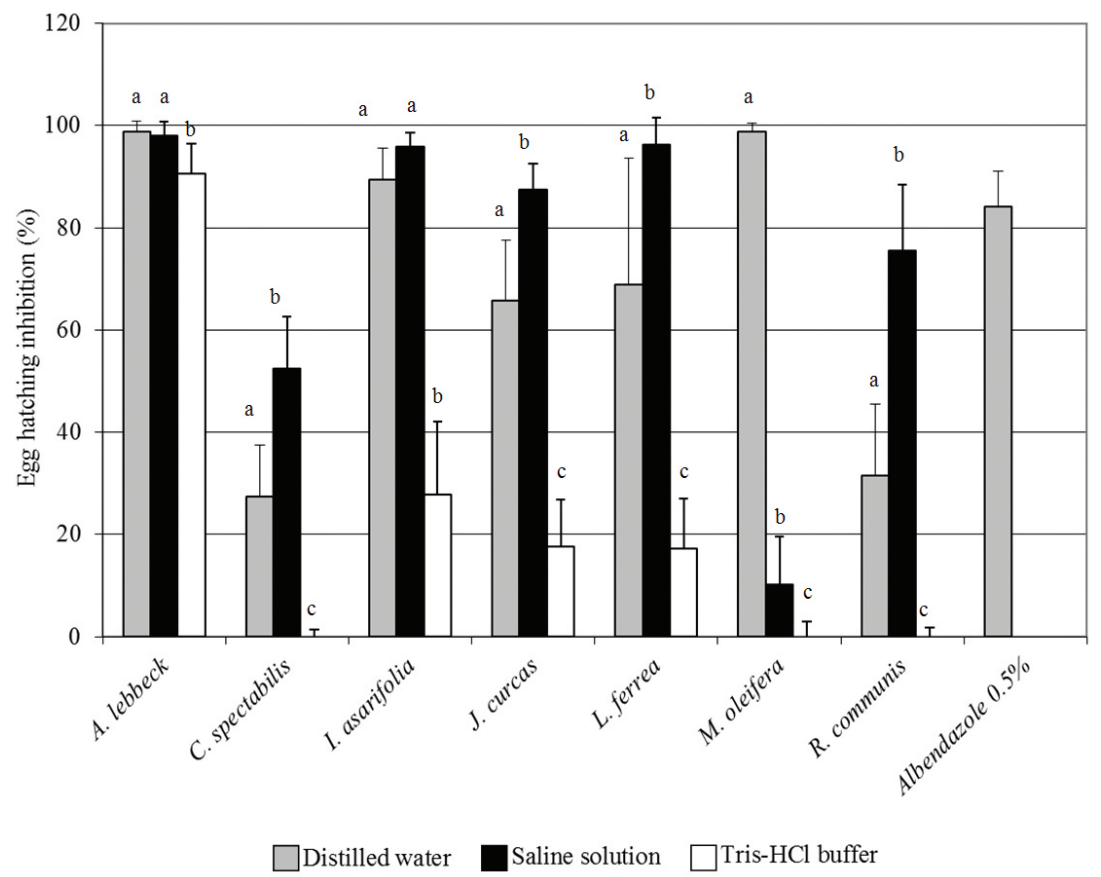

Figure 2. Effect of vegetal extracts on the egg hatch inhibition of Haemonchus contortus. The assay was performed in 24-well plates (0.4 mL with 100 eggs) and the same amount of protein from the crude extracts was used per well (100 $\mu$ g of protein). Albendazole $0.5 \%$ (w/v) in distilled water was the positive control. Extraction solvents: distilled water; saline solution (150 mM NaCl); Tris- $\mathrm{HCl}$ buffer $(25 \mathrm{mM} \mathrm{Tris-HCl}$, $\mathrm{pH}$ 7.5). Values are expressed as means \pm standard deviation. Different letters indicate statistically significant differences $(\mathrm{P}<0.05)$ between solvents for each vegetal species (Bonferroni test). The results were obtained from the three replications of each treatment. 
A. lebbeck extracts extracted with Tris- $\mathrm{HCl}$ buffer. The difference in the efficacy of these types of extracts may be due to the presence of different active compounds.

In addition to egg hatch inhibition and regardless of the solvent used, in the presence of $R$. communis extracts, the larvae $\left(\mathrm{L}_{1}\right)$ of eggs that were able to hatch were found to be dead, which is indicative of the larvicidal property of these extracts.

The crude extracts with the highest ovicidal activity were selected from each plant and dialyzed. This procedure originated a fraction of the crude extract retained (CER) in the membrane (cutoff $12 \mathrm{kDa}$ ) and another one not retained (CENR). Figure 3 illustrates the inhibitory effect of these fractions. Note the concentration of inhibitory activity in CENR fractions of A. lebbeck, I. asarifolia, $J$. curcas, $L$. ferrea, $M$. oleifera and $R$. communis compared to CER fractions $(\mathrm{P}<0.05$, Bonferroni test). These results indicate the importance of low molecular mass molecules $(<12 \mathrm{kDa})$ that may be of either protein origin (proteins and peptides) or secondary metabolites (e.g., tannins, terpenes, alkaloids).

\section{Hemagglutination, hemolytic and protease inhibitor assays}

The most active fractions obtained after dialyzing the crude extracts (crude extract non-retained fraction, Figure 3) revealed the presence of lectin from C. spectabilis and M. oleifera, hemolysin from $A$. lebbeck and $M$. oleifera, trypsin inhibitor from A. lebbeck, I. asarifolia, J. curcas, $M$. oleifera and $R$. communis, and papain inhibitor from $M$. oleifera (Table 1$)$. No activity related to these proteins was detected in the fraction from L. ferrea.

\section{Discussion}

In this study, the in vitro model demonstrated the ovicidal effects of $A$. lebbeck, C. spectabilis, I. asarifolia, J. curcas, L. ferrea, $M$. oleifera and $R$. communis extracts against $H$. contortus, indicating that these plants contain molecules that can disrupt the life cycle of this nematode.

More information can be extracted from the results if one compares the data on CENR fractions in Figure 3 against those of the crude extracts in Figure 2. $R$. communis showed an increase in inhibition efficiency of the CENR fraction in comparison with the crude saline extract. This suggests that the dialysis membrane promoted the isolation/purification of the active molecule, increasing its concentration for the in vitro assay, or that high molecular weight molecules that were interfering in ovicidal activity were removed by dialysis.

Ipomoea asarifolia, J. curcas, L. ferrea and M. oleifera, showed a reduction in the inhibition efficiency of the CENR fraction when compared with the crude extracts, suggesting the presence of two kinds of active molecules in the crude extracts: low molecular weight molecules and high molecular weight molecules. It appears that when they are together, they potentiate the inhibitory effect of the extract, but they may have independent action mechanisms.

The inhibitory activity of $C$. spectabilis was distributed equally between the two fractions, CER and CENR. Since the rates

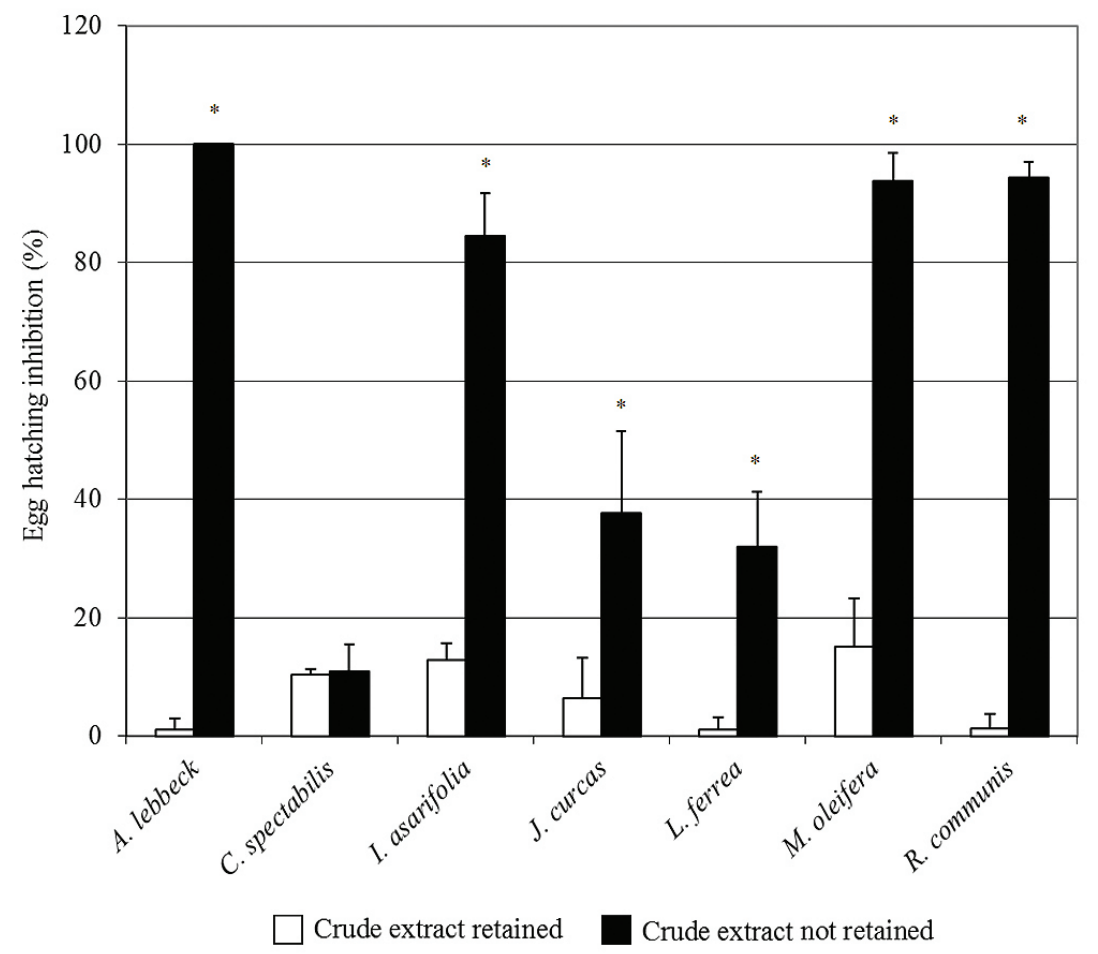

Figure 3. Effects the fractions of the crude extract retained in the dialysis membrane (cutoff $12 \mathrm{kDa}$ ) and of the crude extract not retained on the egg hatch inhibition of Haemonchus contortus. Values are expressed as means \pm standard deviation. $\left.{ }^{*}\right)$ indicates statistically significant differences $(\mathrm{P}<0.05)$ for each vegetal species (Bonferroni test). 
Table 1. Specific activity for lectin, hemolysin, trypsin inhibitor and papain inhibitor in the fractions of crude extract not retained in the dialysis membrane (cutoff $12 \mathrm{kDa}$ ) for each analyzed seed.

\begin{tabular}{lcccc}
\hline \multicolumn{1}{c}{ Seeds } & $\begin{array}{c}\text { Hemagglutination activity } \\
(\text { HU.mg }\end{array}$ & $\begin{array}{c}\text { Hemolytic activity } \\
(\text { HU.mg }\end{array}$ & $\begin{array}{c}\text { Trypsin inhibition activity } \\
\left(\mathbf{I U}_{\left.\mathbf{m} \mathbf{m}^{-1}\right)}\right.\end{array}$ & $\begin{array}{c}\text { Papain inhibition activity } \\
\left(\mathbf{I U} . \mathbf{m g}^{-1}\right)\end{array}$ \\
\hline Albizia lebbeck & - & 547.01 & 1102.56 & - \\
Crotalaria spectabilis & 24.39 & - & - & - \\
Ipomoea asarifolia & - & - & 219.82 & - \\
Jatropha curcas & - & - & 906.04 & - \\
Libidibia ferrea & - & - & - & - \\
Moringa oleifera & 129.03 & 258.06 & 2079.95 & 887.10 \\
Ricinus communis & - & - & 120.97 & - \\
\hline
\end{tabular}

(-) no reaction.

obtained for these fractions (Figure 3) were much lower than in crude saline extract (Figure 2), it appears that the two types of active molecules, i.e., with high and low molecular weights, must work jointly in order to achieve good egg hatch inhibition.

The rate of inhibition of $A$. lebbeck was maintained, suggesting that the active molecules were only low molecular weight molecules $(<12 \mathrm{kDa})$ and that the crude extract did not contain interference or stimulant molecules.

Ovicidal compounds may be able to interrupt embryonic development, impair the survival of larvae inside the egg, or block egg hatching. In the assays with CENR fractions of $A$. lebbeck and $M$. oleifera, it was observed that unhatched eggs were embryonated; hence, the mechanism of action of the bioactive molecules of these two species appears not to interfere in embryonic development. However, the eggs treated with CENR fractions from the other five plant species were unembryonated, suggesting that the bioactive molecules in these plants interfere with embryonic development.

To the best of the author's knowledge, except for J. curcas seeds (EGUALE; GIDAY, 2009), there are no published studies about the anthelmintic effect of the other six seed species extracted with water, saline solution or Tris- $\mathrm{HCl}$ buffer for the control of $H$. contortus egg hatching. Moreover, no scientific studies for any of the seeds were found in a search for plant molecules with protein-triggered ovicidal activity against $H$. contortus.

A recent study on $A$. lebbeck (LAM; NG, 2011b) reports for the first time an anti-tumor, anti-fungal, anti-yeast and anti-bacterial hemolysin with $5.5 \mathrm{kDa}$ called lebbeckalysin, derived from the seeds of this plant. In our study of this plant, ovicidal activity was observed only in the fraction with low molecular weight molecules $(<12 \mathrm{kDa})$. This fraction also showed hemolytic activity. However, although lebbeckalysin may be a strong candidate to be the ovicidal molecule in the CENR fraction of $A$. lebbeck, this fraction also showed strong trypsin inhibitor activity (Table 1), suggesting that there is another candidate molecule for the activity.

The efficacy of $C$. spectabilis in plant parasitic nematode management is well known (WANG et al., 2002), but when compared to the other plants of this study, the results were not sufficiently promising to select this plant as a source of anthelmintic molecules.

Good results were obtained with I. asarifolia seed extracts and fractions. The CENR fraction presented trypsin inhibitory activity (Table 1), However, we found no studies in the literature about trypsin inhibitor derived from $I$. asarifolia or activity from this plant against nematodes that could support these findings.

The toxicity of $J$. curcas seeds to $H$. contortus eggs has already been detected in aqueous extract, which induced significant dosedependent egg hatch inhibition (EGUALE; GIDAY, 2009), the authors did not investigate the active principle. We also observed anthelmintic activity in water extracts, but the saline extracts showed higher egg hatch inhibition (Figure 2). Analyzing these results and comparing them with those in Figure 3 may suggest that there is more than one active principle. Therefore, high and low molecular weight molecules (cutoff $12 \mathrm{kDa}$ ) appear to act together to inhibit egg hatching, and trypsin inhibitor may be one of the candidates for this activity (Table 1). Libidibia ferrea is the basionym of Caesalpinia ferrea (IPNI, 2009) and, in this work, no protein activity was observed in the CENR fraction. It is therefore possible that a type of protein activity other than lectin, hemolysin or protease inhibitor may be present, or that secondary metabolites are the active molecules. For example, analgesic action and anti-inflammatory activity have already been detected in saline extracts of $L$. ferrea pods (FREITAS et al., 2012).

Only crude water extract of $M$. oleifera showed high egg hatch inhibition (Figure 2) and this activity was present only in the fraction of the crude extract not retained in the dialysis membrane. These results suggest that the active molecule is water soluble and has a low molecular weight $(<12 \mathrm{kDa})$. Considering that hemagglutination activity was observed in this fraction (Table 1), a strong candidate for ovicidal activity is a flocculation protein from $M$. oleifera with a molecular mass of $6.5 \mathrm{kDa}$ (GASSENSCHMIDT et al., 1995; NDABIGENGESERE et al., 1995), which has reportedly shown larvicidal activity (COELHO et al., 2009) and ovicidal activity against $A$. aegypti (SANTOS et al., 2012). However, the CENR fraction from $M$. oleifera showed other protein activities that cannot be ignored, such as hemolysin and protease inhibitors (Table 1). Therefore, the active compounds in this fraction should be purified and characterized in the future to investigate their mechanisms of action.

In this study, ovicidal activity was observed only in the CERN fraction of $R$. communis; hence, the active molecules have a low molecular weight $(<12 \mathrm{kDa})$. Therefore, the ricin protein, a toxic protein with $60 \mathrm{kDa}$ which is contained in $R$. communis seeds (WORBS et al., 2011), cannot be the active compound against $H$. contortus eggs, although it is known that the surface of H. contortus eggshells contains galactose carbohydrate (PALMER; 
McCOMBE, 1996; JURASEK et al., 2010; HILLRICHS et al., 2012), which is a binding site for ricin.

Trypsin inhibitor activity, albeit weak, was also observed in the CERN fraction of $R$. communis. It is therefore likely that there is another type of active protein or peptide not analyzed in this study, or an active secondary metabolite such as the alkaloid ricinin, for example.

In conclusion, the obtained results demonstrate the potential of the plants under study as sources of anthelmintic molecules,suggesting that some proteins or peptides may be the active substances. Further purification techniques will be developed to isolate the bioactive molecules and confirm or refute this hypothesis.

\section{Acknowledgements}

The authors thank the Brazilian institutions CNPq (National Council for Scientific and Technological Development), FUNCAP (Ceará Research Foundation, EMBRAPA (Brazilian Agricultural Research Corporation), UVA (Acaraú Valley State University) and BNB-FUNDECI - Banco do Nordeste do Brasil for their support of this research.

\section{References}

Abe M, Abe K, Kuroda M, Arai S. Corn kernel cysteine proteinase inhibitor as a novel cystatin superfamily member of plant origin: molecular cloning and expression studies. Eur J Biochem 1992; 209(3): $933-$ 7. PMid:1425699. http://dx.doi.org/10.1111/j.1432-1033.1992. tb17365.x

Amarante AF, Bricarello PA, Rocha RA, Gennari SM. Resistance of Santa Ines, Suffolk and Ile de France sheep to naturally acquired gastrointestinal nematode infections. Vet Parasitol 2004; 120(1-2): 91106. PMid:15019147. http://dx.doi.org/10.1016/j.vetpar.2003.12.004

Bateman KS, James MNG. Plant protein proteinase inhibitors: structure and mechanism of inhibition. Curr Protein Pept Sci 2011; 12(5): 341-7. http://dx.doi.org/10.2174/138920311796391124

Bone LW, Bottjer KP. Cuticular carbohydrates of three nematode species and chemoreception by Trichostrongylus colubriformis. J Parasitol 1985; 71(5): 235-8. PMid:3998961. http://dx.doi. org/10.2307/3281908

Bradford MM. A rapid and sensitive method for the quantitation of microgram quantities of protein utilizing the principle of proteindye binding. Anal Biochem 1976; 72(1-2): 248-54. http://dx.doi. org/10.1016/0003-2697(76)90527-3

Carbonaro M, Grant G, Cappelloni M, Pusztai A. Perspectives into factors limiting in vivo digestion of legume proteins: antinutritional compounds or storage proteins? J Agric Food Chem 2000; 48(3): 742-9. PMid:10725143. http://dx.doi.org/10.1021/jf991005m

Carlini CR, Grossi-de-Sá MF. Plant toxic proteins with insecticidal properties: a review on their potentialities as bioinsecticides. Toxicon 2002; 40(11): 1515-39. http://dx.doi.org/10.1016/S00410101(02)00240-4

Coelho JS, Santos ND, Napoleão TH, Gomes FS, Ferreira RS, Zingali RB, et al. Effect of Moringa oleifera lectin on development and mortality of Aedes aegypti larvae. Chemosphere 2009; 77(7): 934-8. PMid:19747711. http://dx.doi.org/10.1016/j.chemosphere.2009.08.022

Eguale T, Giday M. In vitro anthelmintic activity of three medicinal plants against Haemonchus contortus. Int J Green Pharm 2009; 3(1): 29 34. http://dx.doi.org/10.4103/0973-8258.49371

Freitas ACC, Ximenes NCA, Aguiar JS, Nascimento SC, Lins TUL, Magalhães LR, et al. Biological activities of Libidibia (Caesalpinia) ferrea var. parvifolia (Mart. ex Tul.) L. P. Queiroz Pod Preparations. Evid Based Complement Alternat Med 2012; 2012: 514134.

Gassenschmidt U, Jany KD, Tauscher B, Niebergall H. Isolation and characterization of a flocculating protein from Moringa oleifera Lam. Biochim Biophys Acta 1995; 1243(3): 477-81. http://dx.doi. org/10.1016/0304-4165(94)00176-X

Githiori JB, Athanasiadou S, Thamsdorg SM. Use of plants in novel approaches for control of gastrointestinal helminths in livestock with emphasis on small ruminants. Vet Parasitol 2006; 139(4): 308-20. PMid:16725262. http://dx.doi.org/10.1016/j.vetpar.2006.04.021

Hashmi S, Britton C, Liu J, Guiliano DB, Oksov Y, Lustigman S. Cathepsin L is essential for embryogenesis and development of Caenorhabditis elegans. J Biol Chem 2002; 277(5): 3477-86. PMid:11707440. http://dx.doi.org/10.1074/jbc.M106117200

Hillrichs K, Schnieder T, Forbes AB, Simcock DC, Pedley KC, Simpson HV. Use of fluorescent lectin binding to distinguish Teladorsagia circumcincta and Haemonchus contortus eggs, third-stage larvae and adult worms. Parasitol Res 2012; 110(1): 449-58. PMid:21732182. http:// dx.doi.org/10.1007/s00436-011-2511-4

Hubert J, Kerboeuf D. A new method for culture of larvae used in diagnosis of ruminant gastrointestinal strongylosis: comparison with fecal cultures. Can J Comp Med 1984; 48(1): 63-71. PMid:6713260 PMCid:PMC1236007.

International Plant Names Index - IPNI. Database. IPNI; 2009. Available from: http://www.ipni.org/.

Jurasek ME, Bishop-Stewart JK, Storey BE, Kaplan RM, Kent ML. Modification and further evaluation of a fluorescein-labeled peanut agglutinin test for identification of Haemonchus contortus eggs. Vet Parasitol 2010; 169(1-2): 209-13. PMid:20060646. http://dx.doi. org/10.1016/j.vetpar.2009.12.003

Kakade ML, Rackis JJ, McGhee JE, Puski G. Determination of trypsin inhibitor activity of soy products: a collaborative analysis of an improved procedure. Cereal Chem 1974; 51(3): 376-81.

Lam SK, Ng TB. Lectins: production and practical applications. Appl Microbiol Biotechnol. 2011a; 89(1): 45-55. PMid:20890754 PMCid:PMC3016214. http://dx.doi.org/10.1007/s00253-010-2892-9

Lam SK, Ng TB. First report of an anti-tumor, anti-fungal, antiyeast and anti-bacterial hemolysin from Albizia lebbeck seeds. Phytomedicine 2011b; 18(7): 601-8. PMid:20850957. http://dx.doi. org/10.1016/j.phymed.2010.08.009

Maciel MV, Morais SM, Bevilaqua CML, Camurça-Vasconcelos ALF, Costa CTC, Castro CMS. Ovicidal and larvicidal activity of Melia azedarach extracts on Haemonchus contortus. Vet Parasitol 2006; 140(1-2): 98-104. PMid:16621294. http://dx.doi.org/10.1016/j.vetpar.2006.03.007

Mansfield LS, Gamble HR, Fetterer RH. Characterization of the eggshell of Haemonchus contortus - I. Strutural components. Comp Biochem Physiol B 1992; 103(3): 681-6. http://dx.doi.org/10.1016/03050491(92)90390-D 
Ndabigengesere A, Narasiah KS, Talbot BG. Active agents and mechanism of coagulation of turbid waters using Moringa oleifera. Wat Res 1995; 29(2): 703-10. http://dx.doi.org/10.1016/00431354(94)00161-Y

Palmer DG, McCombe IL. Lectin staining of trichostrongylid nematode eggs of sheep: rapid identification of Haemonchus contortus eggs with peanut agglutinin. Int J Parasitol 1996; 26(4): 447-50. http://dx.doi. org/10.1016/0020-7519(96)00009-4

Ríos-de Álvarez L, Jackson F, Greer A, Bartley Y, Bartley DJ, Grant $\mathrm{G}$, et al. In vitro screening of plant lectins and tropical plant extracts for anthelmintic properties. Vet Parasitol 2012; 186(3-4): 390-8. PMid:22130336. http://dx.doi.org/10.1016/j.vetpar.2011.11.004

Rogers WP, Brooks F. The mechanism of hatching of eggs of Haemonchus contortus. Int J Parasitol 1977; 7(1): 61-5. http://dx.doi. org/10.1016/0020-7519(77)90026-1
Santos NDL, Moura KS, Napoleão TH, Santos GK.N, Coelho LCBB, Navarro DMAF, et al. Oviposition-stimulant and ovicidal activities of Moringa oleifera lectin on Aedes aegypti. PLoS One 2012; 7(9): e44840. PMid:22970317 PMCid:PMC3435276. http://dx.doi.org/10.1371/ journal.pone.0044840

Wang KH, Sipes BS, Schmitt DP. Crotalaria as a cover crop for nematode management: a review. Nematropica 2002; 32(1): 35-57.

Worbs S, Köhler K, Pauly D, Avondet MA, Schaer M, Dorner MB, et al. Ricinus communis intoxications in human and veterinary medicine: a summary of real cases. Toxins 2011; 3(10): 1332-72. PMid:22069699 PMCid:PMC3210461. http://dx.doi.org/10.3390/toxins3101332

Yang Y, Qin W, Wei H, Ying J, Zhen J. Characterization of cathepsin B proteinase (AcCP-2) in eggs and larvae stages of hookworm Ancylostoma caninum. Exp Parasitol 2011; 129(3): 215-20. PMid:21925175. http:// dx.doi.org/10.1016/j.exppara.2011.08.018 